\title{
SOSIALISASI APOTEK HIDUP BERBASIS TAMAN RUMAH
}

\author{
Hendri Suparto \\ Progam Studi Ilmu Administrasi Niaga \\ Sekolah Tinggi Ilmu Administrasi Pembangunan Jember \\ *Email: hendrisuparto@gmail.com
}

\begin{abstract}
ABSTRAK
Keanekaragaman hayati yang ada di bumi ini tak hanya digunakan sebagai bahan pangan ataupun untuk dinikmati keindahanannya saja, tetapi juga bermanfaat sebagai bahan untuk mengobati berbagai penyakit. Tanaman yang ada, terutama yang tumbuh di Indonesia dikenal sebagai bahan yang ampuh untuk obat dan digunakan sebagai bahan baku industri obat di Indonesia selain juga sebagai obat-obatan tradisional. Sebenarnya, tanaman yang berguna sebagai obat dapat juga ditemui sehari-hari.

Tanaman seperti kunyit, jahe, jeruk pecel dapat ditanam di pekarangan rumah dan berguna sebagai pengusir berbagai penyakit ringan sehari-hari seperti batuk, masuk angin dan panas dalam. Tak hanya itu, beberapa tanaman yang ada Indonesia terbukti ampuh mengatasi berbagai penyakit yang lebih berat. Beberapa bahkan dipercaya dapat mengatasi penyakit mematikan seperti AIDS, kanker dan sebagainya. Tanaman obat juga dapat dijadikan alternatif berobat yang lebih aman dan alami. Selain itu, tanaman obat juga baik untuk menjaga kecantikan dan kesehatan kulit dan tubuh.

Tanaman obat dapat dikonsumsi dengan cara diolah terlebih dahulu.

Beberapa tanaman obat dapat digunakan sehari-hari dan diolah dengan cara sederhana seperti direbus dan dicampur dengan air atau bahan-bahan lainnya, sedangkan tanaman yang lain diolah secara modern oleh pabrik atau industri rumah tangga dengan cara dikeringkan dan dikemas dalam kemasan yang praktis untuk dikonsumsi.
\end{abstract}

Kata kunci : Apotek, Tanaman, Obat 


\section{A. ANALISIS SITUASI}

Apotik hidup adalah
memanfaatkan sebagian bidang
tanah untuk ditanami tanaman obat-
obatan untuk keperluan sehari-hari.

Budaya tradisional yang masih melekat di masyarakat umum tentunya memberikan dampak yang baik dalam kehidupan sehari-hari. Salah satu contohnya adalah kebiasaan mengkonsumsi obatobatan tradisional yang dapat digunakan untuk mengobati berbagai penyakit.

Obat tradisional umumnya lebih aman karena bersifat alami dan memiliki efek samping yang lebih sedikit dibandingkan obat-obatan kimia. itulah faktor yang menjadikan sebagian orang lebih senang mengkonsumsi obat-obatan alami.

Sehingga memicu masyarakat akan kesadaran menanam tanaman obat pada halaman rumah mereka. Banyak keunggulan apotik hidup untuk kehidupan masyarakat kalangan tertentu. Bayangkan apabila salah satu anggota keluarga sedang sakit, anda bisa mengambil tanaman obat kapan saja bahkan dalam cuaca yang tidak memungkinkan untuk pergi ke dokter. Disamping itu kelebihan apotik hidup adalah biayanya yang sangat murah dan keterjaminan kealamian obatnyapun terjaga karena kita memetiknya sendiri.

Disamping fungsinya sebagai obat, tanaman obat juga marak digunakan untuk menghiasi halaman rumah. Selain memiliki fungsi yang penting, tanaman obat juga mampu menghadapi berbagai penyakit tanaman karena memiliki kandungan zat alami untuk mengatasinya. Oleh sebab itu perawatannyapun cenderung sangat mudah dan sederhana. Ada beberapa macam tumbuhan yang bisa dimanfaatkan sebagai apotek hidup, diantaranya:

1. Temulawak

Temulawak merupakan tanaman obat yang sangat populer di kalangan masyarakat indonesia khususnya masyarakat jawa. Temulawak memiliki khasiat yang lengkap. Temulawak atau juga disebut Curcuma biasanya diberikan kepada

anak-anak untuk menambah nafsu makan. selain itu juga mempunyai khasiat antara lain : 
1. Menghilangkan flek-flek hitam pada wajah dan kandungan minyak pada muka

2. Memperlancar ASI pada wanita yang menyusui.

3. Mengobati penyakit hati atau penyakit liver.

4. Menurunkan kadar kolesterol dalam darah.

2. Jahe

Jahe merupakan salahsatu tanaman yang sering kita temui dalam lingkungan sehari-hari. kandungannyapun banyak digunakan dalam obat-obatan olahan pabrik khususnya produksi obat di indonesia. hal ini dikarenakan iklim di indonesia yang tropis sehingga cocok utuk dikonsumsi. adapun khasiat lainnya antara lain:

1. Mengatasi penyakit Impoten/lemah syahwat.

2. Mengobati batuk dan sakit tenggorokan.

3. Mencegah serta mengobati pegal dan linu.

4. Mengobati masuk angin.

5. Mengobati Reumatik
3. Kunyit

Kunyit merupakan tanaman obat yang juga sering kita temui dalam lingkungan sehari-hari. kunyit dijual sebagai rempah-rempahan untuk bahan baku memasak. disamping itu kunyit sangat berkhasiat untuk mengobati haid tidak lancar. dan seringkali diolah menjadi jamu. Manfaat lain dari kunyit antara lain:

1. Memperlancar ASI.

2. Mengobati diabetes mellitus.

3. Mengobati Tifus atau demam.

4. Meringankan sakit Amandel.

4. Kencur

Kencur (kaempferia galangga) merupakan jenis tanaman yang memiliki batang semu yang sangat pendek. Bentuknya cenderung mirip dengan kunyit atau kunir. selain digunakan sebagai bumbu dapur, masyarakat sunda juga sering menkonsumsi sebagai lalapan mentah.

1. Merupakan obat alami untuk influenza dan batuk bagi bayi.

2. Menurunkan berat badan dan melangsingkan tubuh.

3. Sebagai obat sakit kepala 
4. Mengobati diare yang tidak akut.

5. Menghilangkan lelah dan pegal-pegal dibadan.

\section{Daun salam}

Daun salam ternyata mempunyai banyak manfaat untuk kesehatan kita. Bukan hanya untuk menambah sedap masakan kita tetapi daun salam juga ampuh untuk mengobati berbagai penyakit yang dapat diderita oleh semua orang tentunya. Dalam olahan obat alami seringkali kita menemukan racikan yang menggunakan daun salam. berikut ini beberapa manfaat daun salam :

1. Mengobati penyakit diare

2. Mengobati penyakit Diabetes Melitus

3. Mengobati penyakit Maag

4. Mengobati penyakit asam urat

5. Membantu untuk menurunkan kolesterol tinggi 6. Membantu untuk menurunkan tekanan darah tinggi

6. Jambu Biji
Jambu biji juga memiliki khasiat yang cukup penting. Daunnya dapat digunakan untuk mengatasi penyakit buang air atau diare. Fungsi daunnya mampu membuat keras feses sehingga mengurangi buang air besar. jus buahnya juga baik untuk kesehatan karena sangat banyak mengandung vitamin $\mathrm{C}$ serta baik untuk penderita demam seperti Demam Berdarah. manfaat lainnya antara lain:

1. Mengurangi kadar gula dalam tubuh untuk penyakit Diabetes Mellitus

2. Mengurangi penyakit Maag

3. Sakit perut atau Diare pada bayi yang masih menyusui

4. Beser atau sering kencing berlebihan

5. Mengobati luka pada bagian luar tubuh.

6. Mengobati sariawan

\section{Kumis Kucing}

Kumis kucing adalah tumbuhan berbatang basah dan memiliki tinggi $1,5 \mathrm{~m}$. Daunnya berbentuk bulat telur dan bunganya berwarna putih seperti kumis kucing. 
tumbuhan ini merupakan tumbuhan liar yang biasa tumbuh ditepian sungai dan ditempat-tempat basah. Seluruh bagian pada tanaman ini dapat digunakan untuk proses pengobatan. berikut adalah beberapa manfaat dari tanaman ini:

1. Mengatasi susah untuk buang air kencing.

2. Meringankan penyakit batu ginjal

3. Mengobati penyakit kencing manis atau Diabetes Mellitus

4. Meringankan sakit pinggang dan pegal-pegal.

8. Lidah buaya

Lidah buaya merupakan tumbuhan herbal yang kaya akan manfaat dan sangat sering digunakan dalam dunia kesehatan. lidah buaya seringkali dimanfaatkan sebagai obat herbal alami, selain itu lidah buaya juga bermanfaat untuk mengatasi masalah pada jerawat, kulit, menyembuhkan luka dan melebatkan rambut. berikut adalah manfaat lain dari lidah buaya:

1. Detoksifikasi atau meluruhkan kandungan racun

2. Gangguan pencernaan pada usus

3. Menjaga kesehatan mulut
4. Merawat kulit kering

5. Sebagai obat pada luka bakar

6. membantu sistem kekebalan tubuh

9. Jeruk

Jeruk yang berukuran besar atau disebut juga jeruk bali ini merupakan buah yang kaya akan manfaat dan banyak kandungan vitamin yang baik untuk kesehatan tubuh. Bukan hanya pada buahnya saja melainkan pada bunga dan kayunya juga bisa bermanfaat. seperti di vietnam yang menjadikan bunga dari jeruk bali untuk di ekstraksi dan dijadikan parfum aroma terapi. berikut manfaat dari jeruk bali:

1. Menjaga kesehatan jantung dan Anemia

2. Menyembuhkan luka dilambung

3. Kesehatan gusi dan sariawan

4. Mencegah kanker

5. Membantu mencegah Flu dan

Batuk

6. Menjaga tekanan darah

7. Membantu menjaga berat badan dan lemak berlebih

10. Alang-alang 


\begin{abstract}
Alang-alang atau ilalang dikenal sebagai tumbuhan gulma atau tumbuhan pengganggu. Alangalang sering dijumpai hingga ketinggian 2700 Meter diatas permukaan air laut. dan biasanya tumbuh dilahan terbuka atau setengah tertutup. Tumbuhan pengganggu ini bermanfaat sebagai obat untuk menyembuhkan berbagai penyakit. Khasiat kandungan obatnya terdapat pada bagian akarnya yang di ekstrak dan dikonsumsi. berikut adalah beberapa manfaatnya:

1. Sebagai obat untuk radang ginjal akut

2. Sebagai obat untuk muntah darah

3. Sebagai obat untuk kencing nanah

4. Sebagai obat untuk mimisan
\end{abstract}

Tentunya perawatan dan keanekaragaman tanaman obat tidak selalu menjamin akan khasiat yang dihasilkannya. Karena tanaman obat yang akan digunakan tidak akan bekerja secara maksimal apabila proses pengolahannya salah. Oleh sebab itu langkah selanjutnya adalah mempelajari proses pengolahan tanaman obat yang baik dan benar supaya khasiat yang dihasilkan maksimal.

\section{URGENSI PROGRAM}

Tanaman obat adalah jenisjenis tanaman yang memiliki fungsi dan berkhasiat sebagai obat dan dipergunakan untuk penyembuhan atapun mencegah berbagai penyakit. Penggunaan tanaman obat sangat beragam. Terdapat berbagai cara dalam proses penggunaannya seperti diminum, ditempel, ataupun dihirup. Tentunya semua proses itu mengalami tahap pengolahan dengan baik dan benar sebelum dapat digunakan. Dengan peroses pengolahan yang baik dan benar, maka khasiat yang dihasilkan akan lebih tepat dan maksimal.

Pengetahuan masyarakat akan khasiat dari tanaman obat tertentu merupakan hasil dari proses mencoba dan belajar dari kesalahan (trial and error). Hal ini dilakukan manusia sejak lama dan telah menjadi ilmu yang diturunkan dimana khasiatnya diketahui dari hasil penelitian dan pemakaian sendiri oleh masyarakat. Untuk itu, program ini diharapkan dapat 
menjadi percontohan bagaimana mengoptimalkan potensi desa untuk mengelola apotek hidup di pekarangan rumah masing-masing.

\section{TUJUAN DAN MANFAAT} PROGRAM

Program "Program Apotek

Hidup Berbasis Taman Rumah" memiliki tujuan yaitu sebagai berikut:

i. Meningkatkan pemahaman, kesadaran dan ketertarikan masyarakat akan pentingnya menanam tumbuhan apotek hidup.

ii. Meningkatkan pengetahuan masyarakat akan pemanfaatan lahan rumah yang kosong untuk penanaman tumbuhan apotek.

iii. Memberikan pengetahuan masyarakat tentang tanaman hidup yang bisa digunakan untuk obat sebagai apotek hidup.

Dengan demikian, obat-obatan alami yang dibuat dari tanaman hidup memiliki banyak kelebihan dibandingkan dengan obat hasil dari olahan pabrik. Dengan sifatnya yang aman, pengolahan yang sederhana, dan biayanya pun rendah, maka obat tradisional patut dibudidayakan dan dikembangkan oleh masyarakat.

\section{E. DESKRIPSI PROGRAM}

\section{E1. Bentuk Kegiatan}

Program Apotek Hidup Berbasis Taman Rumah memiliki dua kegiatan yaitu sebagai berikut:

1) Sosialisasi apotek hidup di tiga desa di Kecamatan Jenggawah, yaitu Desa Jatisari, Sruni dan Jatimulyo yang akan dilaksanakan pada Sabtu 14 Mei 2019. Sosialisasi di Desa Jatisari dan Desa Sruni dilakukan dengan metode pemaparan dan diskusi kepada kader PKK dan Posyandu desa. Untuk sosialiasi di Desa Jatimulyo dilaksanakan dengan penyebaran pamlet kepada kelompok-kelompok masyarakat di desa.

2) Penyelenggaraan program apotek hidup dilakukan terpusat di Desa Jatisari pada Senin $16 \quad$ Mei 2019. 
Penyelenggaraan apotek hidup secara terpusat di Desa Jatisari dilakukan dengan adanya aktivitas masyarakat yaitu "Program On The Spot" dari tim pelaksana.

\section{E2. Target Group}

Program Apotek Hidup
Berbasis Taman Rumah ini
merupakan program penyuluhan
yang dilaksanakan dengan
melibatkan kelompok-kelompok
masyarakat yang ada di desa seperti
Kader PKK, Kader Posyandu,
Kelompok Pemuda dan Kelompok
Keagamaan.

\section{E3.Target Pencapaian}

Program Apotek Hidup Berbasis Taman Rumah memiliki target pencapaian salah satunya:

1) Target pencapaian sosialisasi, adalah meningkatnya pemahaman dan ketertarikan masyarakat terhadap pemahaman apotek hidup.

2) Target pencapaian penanaman tanaman apotek hidup adalah 45 pendaftar yang diasumsikan dari 3 desa terdapat masing-masing 15 pendaftar.

\section{F. PELAKSANAAN PROGRAM}

\section{F1. Pelaksanaan Sosialisasi}

Pelaksanaan sosialisasi dilaksanakan untuk meningkatkan pemahaman, kesadaran dan ketertarikan masyarakat terhadap kegiatan apotek hidup. Artinya, sosialisasi ini menjadi faktor pendukung utama untuk kesuksesan penyelenggaraan apotek hidup. Sosialisasi dilakukan dengan dua model yaitu temu warga dan model penyebaran pamflet. Pelaksaan

\section{F2. Pelaksanaan Program}

Program Apotek Hidup dilaksanakan pada Senin, 16 Mei 2019 pukul 09.00-12.00 bertempat di balai desa Jatisari Kecamatan Jenggawah. Pendaftar sosialisasi tercatat sebanyak 46 orang. Dari 46 Orang tersebut, ternyata tidak semuanya hadir untuk sosialisasi, karena beberapa alasan, yaitu sebagai berikut:

1. Beberapa peserta tidak memiliki lahan kosong 
(pekarangan rumah) untuk dijadikan taman apotek hidup

2. Beberapa peserta tidak bisa hadir dikarenakan sibuk bekerja.

3. Beberapa peserta tidak hadir tanpa alasan.

Pada pelaksanaan program berlangsung, peseta sosialisasi yang hadir akan diberikan materi terkait sosialisasi tanaman apotek hidup. Agar masyarakat memahami dan bisa membudidayakan tanaman di pekarangan rumahnya. Setelah peserta mengikuti sosialisasi, panitia akan memberikan sejumlah bibit tanaman kepada masyarakat secara rata.

Dari pencapaian pelaksanaan program tersebut, diharapkan masyarakat memahami arti penting hidup sehat tanpa obat, dari segi harga, kesehatan dan cara penggunaannya. Diharapkan untuk kedepannya setelah pelaksanaan sosialisasi ini, masyarakat dapat menerapkan hidup sehat tanpa obat buatan pabrik.

\section{G. PENUTUP}

Demikian

laporan

pengabdian kepada masyarakat dengan tema "Program Apotek Hidup Berbasis Taman Rumah" ini disampaikan. Atas perhatian dan kerjasamanya disampaikan terima kasih.

\section{DAFTAR PUSTAKA}

Agus, A. 2010. Tanaman obat Indonesia. Jakarta: Salemba Medika.

Al-Jauziah. 2008. Ath-thibbun Nabawi, Pengobatan Cara Nabi Muhammad saw. Surabaya: Arkela.

Al-Qardhawi, Y . 2002. Islam Agama Ramah Lingkungan. Jakarta.

Asy-Shayim, M. 2006. Tumbuhan Pilihan, Sehat Alami Secara Islami. Solo: Pustaka Arafah.

Azwar, S. 2007. Metode Penelitian. Yogyakarta. Pustaka Pelajar.

Correa, C. M. 2001. Traditional Knowledge and Intellectual Propety Righ "Issues and 
Surrounding The Protectional Knowledge. Geneva: The Quaker United Nation Office (QUNO).

Dalimarta, G. 2007. Resep Tumbuhan Obat. Jakarta: Penebar Swadaya

Dharma, A. P. 2001. Tanaman Obat Tradisional Indonesia. Jakarta: Balai Pustaka.

Dharmono, 2007. Kajian Etnobotani Tumbuhan Jalukap (Centella asiatica L) di suku Dayak Bukit Desa Haratai 1 Laksado. Banjarmasin, Kalimantan Selatan: Universitas Lampung Mangkurat, Program Studi Pendidikan Biologi FKIP.

Fahreza, I. 2004. Museum Etnobotani Indonesia di Bogor: Dengan Desain Arsitekrur Frank LIyod Weight: Semarang: Universitas Dipenogoro.

Ginting, E. Y. 2012. Studi Etnobotani Penggunaan Tanaman Obat Tradisional Etnis Karo Di Desa Jaranguda Kecamatan
Merdeka Kabupaten Karo. Pendidikan Antropologi Sosial. Fakultas Ilmu Sosial. Universitas Negeri Medan. Skripsi.

Gunawan, D. 2000. Ramuan Tradisional Untuk Keharmonisan SuamiIstri. Jakarta: Penebar Swadaya. 